DOI https://doi.org/10.32782/2305-9389/2020.23.29

УДК 719(438)(091)

Степанюк Софія,

кандидат історичних наук,

стариий викладач кафедри історії України та археології

Волинського національного університету імені Лесі Українки

\title{
ПОЛЬСЬКИЙ ДОСВІД ДЕРЖАВНОГО УПРАВЛІННЯ У СФЕРІ ОХОРОНИ ПАМ'ЯТОК
}

У статті пропонуються аналіз законодавства з охорони та збереження пам'яток та огляд основних державних пам'яткоохоронних інститучій Польщі. Проаналізовано закон «Про охорону $і$ збереження пам'яток» від 23 липня 2003 р. та його подальші доповнення. Розглядаються державні реєстри об 'єктів культурної спадщини, способи внесення пам'яток до реєстрів та ефективність останніх. Виявлено, щзо основною та найефективнішою формою захисту є запис до Реєстру пам'яток (нерухомих, рухомих чи археологічних), який робиться на підставі адміністративного рішення воєводського хранителя пам'яток. Показано еволюиію та механізм дї інституту Генерального хранителя пам'яток та воєводських хранителів пам'яток.

Встановлено, щзо основну діяльність з охорони та збереження пам'яток покладено на Міністерство культури й національної спадщини, а саме: Генерального хранителя пам'яток, Департамент охорони пам'яток та Департамент культурної спадщини.

Розкрито функиії Департаменту охорони пам'яток, серед яких: розробка національної програми охорони та збереження пам'яток та контроль ї̈ виконання; координація та контроль за діяльністю воєводських хранителів пам'яток; надання субсидій на проведення консервачійно-реставраційних або будівельних робіт на історичних будівлях; фінансування археологічних досліджень за кошти Міністерства; перевірка стану збереження пам'яток; опраџювання заявок на нагороди за археологічні знахідки; проведення рекламних та освітніх заходів щзодо охорони пам'яток та догляду за пам'ятками; ведення Переліку скарбів національної спадщини та Національного реєстру нематеріальної спадщини. 3'ясовано, щзо Департамент культурної спадщини опікується рухомими та нематеріальними об 'єктами культурної спадщини. Його діяльність поширюється, зокрема, на діяльність, пов'язану з управлінням музеями та музейними експонатами, а також догляд національних пам'яток за кордоном та здійснення постійних вщанувань пам'яті в місиях національної пам'яті.

Зазначено, щзо в підпорядкуванні Міністерства культури й національної спадщини знаходиться науковий Інститут національної спадщчни, який здійснює надання експертної підтримки міністерству та фахової допомоги в оновленні та публікації реєстрів пам'яток, підтримки у формуванні поглядів міністра та низку іниих завдань.

Ключові слова: Республіка Польща, охорона пам'яток, хранитель пам'яток, Міністерство культури й національної спадщини, Реєстр цінностей національної спадщини, Державний реєстр пам'яток, Муніципальний реєстр пам'яток, Національний інститут спадщчини.

\section{Stepaniuk Sofiia. Polish experience of public administration in the field of monument protection}

The article offers an analysis of the legislation on the protection and preservation of monuments and an overview of the main state monument protection institutions in Poland. The Law "On Protection and Preservation of Monuments" of July 23, 2003 and its subsequent amendments were analyzed. State registers of cultural heritage sites, methods of including monuments in the registers and the effectiveness of the latter are considered. It was found that the main and most effective form of protection is an entry in the Register of Monuments (immovable, movable or archaeological), which is made on the basis of an administrative decision of the voivodship custodian of monuments. The evolution and mechanism of action of the institute of the General Keeper of Monuments and Voivodeship Keepers of Monuments are shown.

It is established that the main activity for the protection and preservation of monuments is entrusted to the Ministry of Culture and National Heritage. Namely, its General Keeper of Monuments, the Department of Monument Protection and the Department of Cultural Heritage.

The functions of the Department of Monument Protection are disclosed, including: development of a national program for the protection and preservation of monuments and control of its implementation; coordination and control over the activities of voivodship custodians of monuments; providing subsidies for conservation and restoration or construction work on historic buildings; financing of archeological research at the expense of the Ministry; checking the status of preservation of monuments; processing applications for awards for archaeological finds; conducting advertising and educational activities for the protection of monuments and care for monuments; maintaining the Register of National Heritage Treasures and the National Register of Intangible Heritage. It has been established that the Department of Cultural Heritage takes care of movable and intangible cultural heritage sites. Its activities include activities related to the management of museums and museum exhibits, as well as the maintenance of national monuments abroad and the implementation of permanent commemorations in places of national memory.

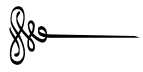


It is noted that the National Heritage Research Institute provides expert support and professional assistance to the Ministry of Culture and National Heritage in updating and publishing registers of monuments, support in forming the Minister's views and a number of other tasks.

Key words: Republic of Poland, protection of monuments, custodian of monuments, Ministry of Culture and National Heritage, Register of National Heritage Values, State Register of Monuments, Municipal Register of Monuments. National Heritage Institute.

Необхідність вивчення успішного досвіду зарубіжних країн у сфері управління культурною спадщиною буде для українців актуальною доти, доки ми не напрацюємо власний. А досвід Польщі для нас актуальний ще й тому, що це постсоціалістична країна, якій після розвалу Радянського Союзу теж потрібно було популяризувати власну культурну спадщину, підвищити рівень культури споживання пам'яток.

До цього часу тема не знайшла широкого відображення в науці. Заслуговує на увагу стаття кандидата юридичних наук Тамари Мазур та доктора історичних наук Івана Мищака, що являє собою порівняльний аналіз пам'яткоохоронного законодавства України та Польщі [1]. Тема нинішньої статті знайшла в статті Т. Мазур та I. Мищака часткове висвітлення. Більше уваги організації пам'яткоохоронної справи Польщі приділили Леонід Прокопенко та Ксенія Гевель у статті «Досвід державного управління у сфері збереження культурної спадщини в країнах СС», де аналізують історію та сучасність збереження культурної спадщини Польщі та Великобританії [2]. Ще одна стаття Ксенії Гевель присвячена зіставленню механізмів збереження культурної спадщини в колишніх країнах соціалістичного табору, таких як Румунія, Болгарія, Словаччина i, зокрема, Польща [3].

У цій статтіпереслідується мета подати якнайширший оглядпольських державних пам'яткоохоронних органів та законодавства у сфері охорони та захисту пам'яток.

Охорона пам'яток Республіки Польща регламентується Законом «Про охорону і збереження пам'яток» від 23 липня 2003 р. [5]. Польське законодавство розділяє поняття охорони пам'яток та збереження пам'яток. Охорона пам'яток здійснюється державними органами, натомість збереженням пам'яток займаються переважно їхні власники та користувачі. Такий підхід до питання охорони пам'яток є імітацією німецьких законодавчих моделей [4, с. 3].

Управління культурною спадщиною в Республіці Польща передбачає діяльність органів державної адміністрації з метою:

- забезпечення правових, організаційних та фінансових умов, що уможливлюють постійне збереження пам'яток, а також їх розвиток та утримання;

- запобігання таким небажаним явищам, як знищення та неналежне використання пам'яток, їх крадіжки, зникнення, незаконний експорт за кордон;

- контроль за станом збереження та призначенням пам'яток;

- врахування пам'яткоохоронних завдань у процесі планування, просторового розвитку та формування навколишнього середовища.

Відповідно до Закону існує п’ять форм охорони пам'яток:

- внесення до Реєстру пам'яток;

- внесення до Переліку скарбів національної спадщини;

- визнання пам'яткою історії;

- створення культурного заповідника;

- встановлення охоронних вимог у комплексному плані просторового розвитку громади або в рішенні про планування і забудову територій [5].

Основною та найефективнішою формою захисту є запис до Реєстру пам'яток (нерухомих, рухомих чи археологічних), який робиться на підставі адміністративного рішення воєводського хранителя пам'яток. Реєстр включає об'єкти надзвичайної вартості, які відрізняються, наприклад стилістикою, просторовою композицією, автентичністю, унікальність, історією, пов'язаною з особистістю автора тощо. Вони перебувають під суворим пам'яткоохоронним захистом, тобто власник під страхом покарання зобов' язаний отримати дозвіл воєводського пам'яткоохоронного органу майже на всі роботи та заходи, що виконуються в пам'ятці або навколо неї. 3 іншого боку, існує можливість співфінансування робіт на пам'ятці, внесених до Реєстру (наприклад, за рахунок субсидії міністра культури та національної спадщини, воєводського консерватора пам'яток або органів місцевого самоврядування), та звільнення від податків (на нерухоме майно, сільське господарство, ліс, спадщину та дарування).

Найціннішим пам'ятникам та культурним заповідникам країни Президент Республіки Польща може присвоїти звання історичної пам'ятки. Однак цей титул є в основному статусним і не передбачає жодного додаткового захисту. Однак це дозволяє полегшити доступ до субсидій та популяризує пам’ятку [6].

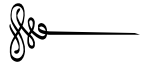


Також існують муніципальні реєстри пам'яток. Це реєстри пам'яток, що ведуться війтами територіальних громад (гмін) або бургомістрами і мерами міст. Вони містять нерухомі пам'ятки, вписані до воєводського реєстру пам'яток, і інші нерухомі об'єкти культурної спадщини, визначені війтом (бургомістром, мером) і погоджені воєводським хранителем пам'яток. Це пам'ятки, значущі для місцевого культурного ландшафту, але не внесені до державного Реєстру пам'яток, а також пам'ятки регіонального характеру. Наприклад, прості дерев'яні будівлі, залишки фільварків, давні промислові споруди, каплиці, хрести та придорожні фігури тощо. Місцеві переписи пам'яток, що зберігалися з 1950-х рр., мали лише інвентаризаційний характер. Єдиною формою їх охорони були відповідні положення місцевого плану просторового розвитку громади, для підготовки яких записи були вихідним матеріалом. Ситуацію змінила поправка до Закону 318 березня 2010 р., яка також внесла зміни до деяких інших актів, включаючи Закон «Про будівництво». Нині охорона пам'яток, включених до муніципального реєстру пам'яток, враховується не лише в місцевому плані просторового розвитку, але й у вигляді відповідних положень рішення про умови забудови, визначення місця інвестиції державного призначення, інвестицій у дороги, розташування залізничної лінії або здійснення інвестицій в аеропорт громадського користування. Найважливіша, одначе, зміна - це необхідність погодження дозволу на будівництво (реконструкцію, прибудову, знесення) з регіональним зберігачем пам'яток, але варто підкреслити, що це зобов'язання покладається на компетентний архітектурний орган, що видає таке рішення, а не на інвестора, і поширюється лише на об'єкти, які не є розташовані в районі, внесеному до реєстру пам'яток. У доповненні 2010 р. не передбачено ані можливості субсидування робіт із пам'яток із записів, ані будь-яких податкових пільг для їхніх власників.

Щодо виконавчої гілки влади, то діяльність з охорони та збереження пам'яток покладена на Міністерство культури й національної спадщини, а саме: Генерального хранителя пам'яток, Департамент охорони пам’яток та Департамент культурної спадщини [7].

Посада Генерального хранителя пам'яток, яку раніше обіймали експерти в галузі, набула політичного змісту. IІЇ обіймає віцеміністр культури і національної спадщини - представник правлячої партії [8]. Нині це заступник держсекретаря Магдалена Гавін [9]. На місцях пам'яткоохоронні функції виконують воєводські управління охорони пам'яток на чолі з воєводськими хранителями пам'яток. Вони приймають рішення щодо внесення пам'яток до державних чи муніципальних реєстрів та проведення будь-яких будівельних робіт із пам'ятками воєводства. Воєводські управління охорони пам'яток формально перебувають у підпорядкуванні безпосередньо Міністерства культури й національної спадщини і Генерального хранителя, а не Департаменту охорони пам'яток (див. рис. 1) [10]. Очільником Департаменту охорони пам'яток своєю чергою $є$ директор департаменту, а не Генеральний хранитель пам'яток [11], хоча на практиці обов'язок координації роботи воєводських хранителів пам'яток спочиває на плечах саме Департаменту.

\section{SCHEMAT PODLEGLOŚCI \\ WOJEWÓDZKIEGO URZĘDU OCHRONY ZABYTKÓW}

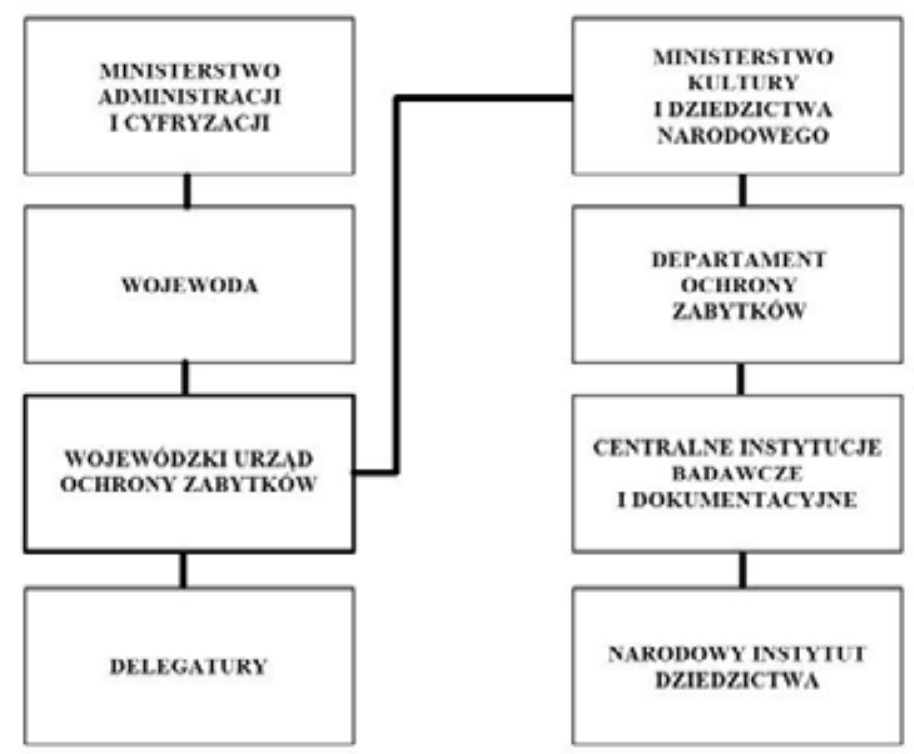

Рис. 1. Схема підпорядкування Восводського управління охорони пам'яток

Джерело: https://www.wkz.lublin.pl/index.php?option=com_content\&view=article\&id=101\&Itemid=97 
До обов'язків Департаменту охорони пам'яток належать:

- виконання та координація виконання завдань, що випливають із політики Ради міністрів у галузі охорони пам'яток;

- розроблення проєкту Національної програми охорони та збереження пам'яток та координація і контроль за виконанням цієї програми;

- розроблення, оновлення та реалізація Національного плану охорони пам'яток на випадок збройного конфлікту та кризи;

- ведення адміністративного судочинства відповідно до компетенцій міністра;

- діяльність у цивільному та судово-адміністративному судочинстві, включаючи представництво міністра перед Верховним судом, Вищим адміністративним судом, воєводськими адміністративними судами та загальними судами згідно з юрисдикцією відповідного департаменту;

- моніторинг основних завдань воєводських управлінь з охорони пам'яток;

- координація та контроль за діяльністю воєводських хранителів пам'яток;

- ведення обліку та збір документації щодо домовленостей між воєводськими хранителями пам'яток із директорами музеїв, компетентними органами територіальних громад та повітів щодо обсягу завдань, доручених охороні пам'яток;

- надання субсидій на проведення консерваційно-реставраційних робіт або будівельних робіт на історичних будівлях, внесених до реєстру пам'яток у рамках програм міністра, фінансування археологічних досліджень за кошти міністерства;

- підготовка аналізів та оцінок щодо функціонування охоронних служб, а також організація, проведення та участь у тренінгах для цих служб;

- підготовка адміністративних рішень, що визначають дебіторську заборгованість міністерства через використання субсидій у надмірному розмірі або із використанням субсидій у надмірному розмірі, в межах компетенції відомства;

- координація питань, пов'язаних із видачею ліцензій на експорт пам'яток;

- перевірка стану збереження пам'яток та правильності застосовуваних адміністративних та консерваційних процедур;

- опрацювання заявок на нагороди за археологічні знахідки;

- опрацювання заявок на отримання премії за археологічні знахідки;

- надання послуг оцінювачам міністра відповідно до компетенції відомства;

- підтримка Ради з охорони пам'яток та Ради з нематеріальної культурної спадщини, що діють при кабінеті міністра;

- підтримка Головного комітету з питань охорони, який діє при Генеральному хранителеві пам'яток;

- нагляд за перебігом конкурсів і премій Генерального хранителя пам'яток та Міністра культури і національної спадщини;

- проведення рекламних та освітніх заходів щодо охорони та збереження пам'яток;

- здійснення спільних заходів 3 охорони пам'яток з урядовими, місцевими, закордонними органами влади;

- виконання повноважень та обов'язків розпорядника Національного фонду охорони пам’яток;

- ведення Переліку скарбів національної спадщини, Національного реєстру нематеріальної спадщини [12].

Департамент культурної спадщини опікується рухомими та нематеріальними об'єктами культурної спадщини. Його діяльність поширюється на:

- ведення організаційних справ, що виникають внаслідок нагляду міністра за музеями та культурними закладами, що діють у сфері політики пам'яті, для яких міністр є організатором або співорганізатором;

- управління музейними експонатами, включно з юридичними діями та справами, пов'язаними 3 видаленням із музейного інвентарю;

- підтримка Ради з питань музеїв та національних меморіалів;

- координація завдань у галузі поширення питань, що стосуються охорони, збереження та спільного використання колекцій, та співпраця в цьому питанні з органами пам'яткоохоронної діяльності та реставраторськими підприємствами;

- координація питань, що стосуються надання Державним казначейством поруки на виплату компенсації за знищення, пошкодження або крадіжку незастрахованих експонатів, що складають художні виставки, організовані музеями та іншими організаторами виставок, які знаходяться в юрисдикції департаменту; 
- ведення справ щодо кваліфікаційних вимог до спеціалістів-музейників та координація справ щодо визнання кваліфікацій, набутих у державах-членах ЄС для виконання професії музейного працівника;

- ведення Державного музейного реєстру;

- ініціювання та координація робіт над стратегіями розвитку музеїв у Польщі та моніторинг змін у законодавстві в галузі музеєзнавства, ініціювання законодавчої діяльності в цій галузі;

- координація промоції музейних колекцій та досягнень польської музеології в країні та за кордоном;

- координація впровадження стандартів музеєзнавства, що випливають із законодавства ЄС, та нагляд за виконанням міжнародних програм та проєктів, пов’язаних із музеями та музеєзнавством, стороною яких є міністр;

- реалізація завдань міністра в галузі підтримання та поширення польських національних та державних традицій;

- обслуговування Міжнародної ради Освенціму;

- виконання завдань міністра, включаючи завдання, що випливають із міжнародних угод, пов'язані 3 доглядом національних пам'яток за кордонами Республіки Польща;

- здійснення постійних вшанувань пам'яті в місцях національної пам'яті, включаючи місця боїв та мученицької смерті представників польської нації, та вшанування пам'яті пов'язаних із цим фактів, подій та цифр [13].

Окремо варто згадати про таку наукову установу, як Інститут національної спадщини, підпорядкований міністерству культури й національної спадщини. Його було утворено у 2011 р., хоча подібні установи працювали в Польщі безперервно 3 60-х років минулого століття [14]. Офіційна Інтернет-сторінка визначає Інститут національної спадщини як державну культурну установу, яка надає експертну підтримку та підтримку у формуванні поглядів міністру культури та національної спадщини. Директора Інституту призначає міністр культури на національної спадщини [15].

За Статутом перед інститутом стоїть широке коло завдань:

- розробка та поширення стандартів документації, досліджень, реставрації та оцифрування рухомих, нерухомих та археологічних пам'яток;

- підключення на вимогу Міністра культури та національної спадщини або Генерального хранителя пам'яток до процесу оцінки та вдосконалення системи охорони та догляду за пам'ятками та до процесу охорони нематеріальної спадщини;

- надання експертних оцінок щодо діяльності, пов'язаної з пам'ятками, для органів державного управління;

- моніторинг та аналіз загроз культурній спадщині та розробка методів протидії цим загрозам;

- публікація та поширення видань про охорону та збереження об'єктів культурної спадщини;

- здійснення спеціалізованих навчальних та інформаційних програм для реставраційних служб та середовищ, пов'язаних зі збереженням пам'яток;

- співпраця з власниками та розпорядниками пам'яток із метою належного управління ресурсом культурної спадщини та пропаганди принципів збереження пам'яток;

- реалізація програм та соціальних кампаній у галузі популяризації культурної спадщини та ії важливості, а також ідеї охорони пам'яток та піклування про пам'ятники;

- реалізація освітніх програм та співпраця в галузі соціальної освіти для охорони та збереження матеріальної та нематеріальної спадщини;

- здійснення співпраці з метою збільшення рівня суспільного інтересу та участі в системі ідентифікації та охорони культурної спадщини;

- збір, обробка, архівування та поширення знань про стан збереження та цінності об’єкта культурної спадщини, включаючи наукові колекції, пов'язані з охороною цієї спадщини;

- внесення записів до державного Реєстру пам'яток та управління ними, а також реєстрація археологічних досліджень, що проводяться у країні;

- створення та розробка загальнодержавної цифрової системи збору та публікації даних про культурну спадщину, включно $з$ даними про геолокацію;

- координація виконання процедури подання запиту міністру про визнання нерухомого об'єкта культурної спадщини історичною пам'яткою президентом Республіки Польща;

- виконання доручень міністра, що випливають з угод, конвенцій та інших документів, ратифікованих Польщею, щодо охорони та догляду за матеріальною та нематеріальною культурною спадщиною;

- проведення за погодженням із Міністром міжнародної співпраці у галузі охорони та збереження об'єктів культурної спадщини;

- організація та проведення інших робіт, пов'язаних з охороною культурної спадщини, на прохання Міністра чи Генерального хранителя пам'яток.

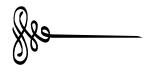


Одними з найважливіших завдань інституту залишаються оновлення та публікація державного Реєстру пам'яток. Інститут національної спадщини нараховує 14 територіальних відділень і майстерень у великих містах та три спеціалізовані територіальні майстерні. Інститут виконує свої завдання, співпрацюючи з реставраційними службами та іншими організаціями, що спеціалізуються на охороні та збереженні пам'яток, включаючи університети, наукові установи, культурні установи, музеї, церкви та релігійні об'єднання, а також адміністрацію місцевого самоврядування та неурядові організації [16].

Таким чином, у Республіці Польща охорона та захист об’ єктів культурної спадщини пам’яток регламентуються Законом «Про охорону і збереження пам'яток» від 23 липня 2003 р. із подальшими доповненнями. Пам'яткоохоронною діяльністю займається розлога система органів державної адміністрації, серед яких - Департамент охорони пам'яток та Департамент культурної спадщини Міністерства культури й національної спадщини та воєводські управління охорони пам'яток на чолі з Генеральним хранителем пам'яток. Надання експертної підтримки міністерству та фахової допомоги в оновленні та публікації реєстрів пам'яток, підтримки у формуванні поглядів міністра та низку інших завдань виконує науковий Інститут національної спадщини. Подальше висвітлення успішного досвіду у сфері управління культурною спадщиною сусідніх країн, на нашу думку, дасть змогу покращити рівень охорони та збереження пам’яток в Україні.

\section{Література:}

1. Мазур Т., Мищак І., Законодавство у сфері охорони культурної спадщини в Польщі та Україні: порівняльний аналіз. Вісник Національної академії керівних кадрів культури і мистецтвв. 2019 . № 1. С. 166-172.

2. Прокопенко Л., Гевель К. Досвід державного управління у сфері збереження культурної спадщини в країнах ЄС. Державне управління та місиеве самоврядування. Вип.1 (12). 2012. С. 73-82

3. Гевель К. Збереження культурної спадщини у посткомуністичних країнах Євросоюзу. Актуальні проблеми державного управління. 2010. Вип. 4. С. 74-77.

4. Kurzątkowski M. Mały słownik ochrony zabytków. Warszawa, 1989. 457 c.

5. Obwieszczenie Marszałka Sejmu Rzeczypospolitej Polskiej z dnia 6 lutego 2020 r. w sprawie ogłoszenia jednolitego tekstu ustawy o ochronie zabytków i opiece nad zabytkami. URL: http://isap.sejm.gov.pl/isap.nsf/DocDetails. xsp?id=WDU20200000282

6. Pasek W. Forma i sposób ochrony zabytków. Komisja Opieki nad zabytkami Zarząu Głównego Polskiego Towarzystwa Turystyczno-Krajoznawczego. URL: http://konz.pttk.pl/artykuly/23-forma-i-sposob-ochrony-zabytkow(дата звернення: 13.10.2020).

7. Ministerstwo Kultury i Dziedzictwa Narodowego. URL: https://www.gov.pl/web/kultura/ (дата звернення: 13.10.2020).

8. Generalny Konserwator Zabytków. Wikipedia: wolna encyklopedia. URL: https://pl.wikipedia.org/wiki/Generalny_ Konserwator_Zabytk\%C3\%B3w (дата звернення: 13.10.2020).

9. Magdalena gawin. URL: https://www.gov.pl/web/kultura/magdalena-gawin (дата звернення: 13.10.2020).

10. URL: https://www.wkz.lublin.pl/index.php?option=com_content\&view=article\&id=101\&Itemid=97 (дата звернення: 14.10.2020).

11. Departament Ochrony Zabytków Ministerstwa Kultury i Dziedzictwa Narodowego URL: https://www.gov.pl/web/kultura/ departament-ochrony-zabytkow (дата звернення: 15.10.2020).

12. Zakres Działalności Departamentu Ochrony Zabytków URL: https://www.gov.pl/web/kultura/departament-ochronyzabytkow (дата звернення: 15.10.2020).

13. Departament Dziedzictwa Kulturowego Ministerstwa Kultury i Dziedzictwa Narodowego. URL: http://bip.mkidn.gov.pl/ pages/departamenty-i-biura/departament-dziedzictwa-kulturowego.php (дата звернення: 15.10.2020).

14. Narodowy Instytut Dziedzictwa. Wikipedia: wolna encyklopedia. URL: https://pl.wikipedia.org/wiki/Narodowy_Instytut_ Dziedzictwa (дата звернення: 15.10.2020).

15. Narodowy Instytut Dziedzictwa. URL: https://nid.pl (дата звернення: 16.10.2020).

16. Statut Narodowego Instytutu Dziedzictwa. URL: https://nid.pl/pl/O_NID/Statut (дата звернення: 16.10.2020). 